\title{
Electromagnetic Fields and Human Endocrine System
}

\author{
Michal Karasek ${ }^{1,2, \star}$ and Marta Woldanska-Okonska ${ }^{3}$ \\ ${ }^{1}$ Department of Electron Microscopy, Chair of Pathomorphology, Medical University of Lodz; \\ ${ }^{2}$ Department of Endocrinology and Isotope Therapy, Medical University of Lodz; Polish \\ Mother's Memorial Hospital - Research Institute, Lodz; ${ }^{3}$ Chair of Rehabilitation, Swietokrzyska \\ Academy, Branch of Piotrkow, Poland \\ E-mail: karasek@csk.am.lodz.pl
}

Received June 22, 2004; Revised August 18, 2004; Accepted August 18, 2004; Published October 20, 2004

\begin{abstract}
Extremely low frequency electromagnetic fields (ELF EMF) are commonly present in daily life all over the world. Moreover, EMF are used in the physiotherapy of many diseases because of their beneficial effects. There is widespread public concern that EMF may have potential consequences for human health.

Although experimental animal studies indicate that EMF may influence secretion of some hormones, the data on the effects of EMF on human endocrine system are scarce. Most of the results concentrate on influence of EMF on secretion of melatonin. In this review, the data on the influence of EMF on human endocrine system are briefly presented and discussed.
\end{abstract}

KEYWORDS: electromagnetic fields, endocrine system, hormones

DOMAINS: microscopy, medicine, endocrinology, sport medicine and physiotherapy.

\section{INTRODUCTION}

Extremely low frequency electromagnetic fields (ELF EMF) are commonly present in daily life all over the world. They are associated with the use of electric power applied in residential and occupational environments. Wherever electricity is generated, transmitted, or used, electric and magnetic fields are created due to the presence of motion of electric charges. They are emitted by power lines, electrical panels, transformers, and service wires, but also by such household appliances as televisions, electric blankets, hair driers, etc.[1]. Moreover, electromagnetic fields (EMF) are used in the physiotherapy of many diseases (e.g., low back pain syndrome, migraine and vasomotoric headaches, multiple sclerosis, degenerative processes of the bones and joints, rheumatoid arthritis) because of their beneficial effects (e.g., improvement of soft tissue regeneration processes, vasodilatory action, acceleration of bone adhesion formation, anti-inflammatory and analgesic action)[2,3].

There is widespread public concern that EMF may have potential consequences for human health[1,4,5], especially associated with increased risk for cancer and childhood leukemia[5]. 
Additionally some attention has also been paid to other possible health hazards, such as interference with cardiac pacemakers[6], Alzheimer’s disease[7], and adverse pregnancy outcome[8].

Although there is still scientific controversy concerning that problem, it seems to be a growing consensus that human health hazard associated with exposure to EMF is either very small or restricted to small subgroups. A Working Group organized by the National Institute of Environmental Health Services concluded in a report published in 1998, on the basis of almost 900 publications, that: "None of the evidence for adverse health effects seen after exposure to ELF EMF achieved a degree of evidence exceeding 'inadequate’ (for humans) or 'weak' (for experimental animals)’'[1].

Studies on the effects of EMF in humans concentrate mainly on power line frequency fields or fields used in mobile phones. The influence of ELF EMF used in physiotherapy on the endocrine system was rarely examined.

Although experimental animal studies indicate that EMF may influence secretion of some hormones[9,10,11,12,13,14], the data on the effects of EMF on the human endocrine system are scarce. Most of the results concentrate on the influence of EMF on secretion of melatonin. In this review, the data on the influence of EMF on the human endocrine system are briefly presented and discussed.

\section{ELECTROMAGNETIC FIELDS AND MELATONIN}

The data on the influence of EMF on melatonin secretion in humans are controversial. Although EMFinduced suppression on nocturnal melatonin secretion has been reported in occupational and residential studies[15,16,17,18,19,20], in the majority of laboratory-based exposure studies[21,22,23,24,25,26,27, 28,29,30,31,32,33,34,35,36,37,38,39], EMF did not exert a distinct influence on melatonin or 6hydroxymelatonin concentrations[see 40] (Table 1). According to Karasek et al.[28,40], discrepancies in the results may depend on different experimental paradigms, including differences in certain characteristics of the applied magnetic fields, such as field induction, frequency, duration of exposure, timing of exposure, applied vector, etc.

\section{ELECTROMAGNETIC FIELDS AND PITUITARY HORMONES}

No significant effects of EMF on the secretion of growth hormone and FSH have been found[32,39,41,42] (Table 2). Chronic application of $2.9 \mathrm{mT}, 50 \mathrm{~Hz}$ EMF lowered the level of LH, whereas no changes were observed after chronic exposure to 25-80- $\mu \mathrm{T}, 200 \mathrm{~Hz}$ EMF[42] and acute exposure to $10 \mu \mathrm{T}, 40 \mathrm{~Hz}$ (continuous or intermittent)[41] or to GSM-standard[32]. Woldanska-Okonska et al.[42] observed a decrease in prolactin concentrations following chronic application of EMF (25-80 $\mu \mathrm{T}, 200 \mathrm{~Hz}$ and $2.9 \mathrm{mT}, 40 \mathrm{~Hz}$, for 3 weeks) whereas acute exposure to $1 \mu \mathrm{T}, 50 \mathrm{~Hz}[30]$ or $20 \mu \mathrm{T}, 50 \mathrm{~Hz}$ did not influence the concentrations of this hormone[39].

\section{ELECTROMAGNETIC FIELDS AND PITUITARY - THYROID AXIS}

Generally, EMF did not significantly influence hormones secreted by pituitary - thyroid axis[41,43] (Table 2). However, Woldanska-Okonska and Czernicki[43] observed differences in fT3 and fT4 levels after exposure to EMF of $2.9 \mathrm{mT}, 40 \mathrm{~Hz}$ in comparison to 25-80 $\mu \mathrm{T}, 200 \mathrm{~Hz} 1$ month following 3-weeks application. Moreover, among the studied patients, the authors have found the individuals especially sensitive to EMF in terms of secretion of TSH, fT3, and fT4. 
TABLE 1

Effects of Electromagnetic Fields on Melatonin or 6-Hydroxymelatonin Sulfate (6-OHMS) Concentrations in Humans[40, modified]

\begin{tabular}{|c|c|c|c|}
\hline Exposure Parameters & Exposure Duration & Outcome & Ref. \\
\hline \multicolumn{4}{|c|}{ Melatonin } \\
\hline 150 mT (MRI) & $40.5 \mathrm{~min}$ & No effect & [21] \\
\hline $1.5 \mathrm{~T}(\mathrm{MRI})$ & $60 \min (01: 00-02: 00)$ & No effect & [22] \\
\hline $\begin{array}{l}10 \mu \mathrm{T}, 50 \mathrm{~Hz} \text { (continuous) } \\
10 \mu \mathrm{T}, 50 \mathrm{~Hz} \text { (intermittent) }\end{array}$ & $9 \mathrm{~h}(23: 00-08: 00)$ & No effect & [23] \\
\hline $\begin{array}{l}1 \mu \mathrm{T}, 60 \mathrm{~Hz} \text { (intermittent) } \\
20 \mu \mathrm{T}, 60 \mathrm{~Hz} \text { (continuous) }\end{array}$ & $8 \mathrm{~h}(23: 00-07: 00)$ & $\begin{array}{l}\text { No effect (reduction in men } \\
\text { with low baseline melatonin) }\end{array}$ & [24] \\
\hline $20 \mu \mathrm{T}, 50 \mathrm{~Hz}$ (continuous) & 8 h (23:00-07:00) & No effect & [25] \\
\hline $20 \mu \mathrm{T}, 50 \mathrm{~Hz}$ & $1.5-4 \mathrm{~h}$ (at night) & No effect (delayed rise) & [26] \\
\hline $2.9 \mathrm{mT}, 40 \mathrm{~Hz}$ & $\begin{array}{l}3 \text { weeks ( } 16 \mathrm{~min} / \text { day, } 5 \\
\text { days/week) }\end{array}$ & Decrease & [27] \\
\hline $25-80 \mu \mathrm{T}, 200 \mathrm{~Hz}$ & $\begin{array}{l}3 \text { weeks ( } 16 \mathrm{~min} / \text { day, } 5 \\
\text { days/week) }\end{array}$ & No effect & [28] \\
\hline $1 \mu \mathrm{T}, 50 \mathrm{~Hz}$ & $10 \mathrm{~h}(22: 00-08: 00)$ & No effect & [29] \\
\hline $28.3 \mu \mathrm{T}, 60 \mathrm{~Hz}$ & $8 \mathrm{~h}(23: 00-07: 00)$ & No effect & [30] \\
\hline $100 \mu \mathrm{T}, 50 \mathrm{~Hz}$ (continuous or intermittent) & $30 \min (13: 30-16: 30)$ & No effect & [31] \\
\hline $\begin{array}{l}\text { GSM-standard: } 900 \mathrm{MHz} \text {, pulsed with } 217 \\
\mathrm{~Hz} \text {, pulse width of } 577 \mu \mathrm{s}\end{array}$ & 8 h (23:00-07:00) & No effect & [32] \\
\hline $\begin{array}{l}\text { GSM-standard: } 900 \mathrm{MHz} \text {, pulsed with } 217 \\
\mathrm{~Hz} \text {, pulse width of } 576 \mu \mathrm{s}\end{array}$ & $\begin{array}{l}4 \text { weeks ( } 2 \text { h/day, } 5 \\
\text { days/week) }\end{array}$ & No effect & [33] \\
\hline $\begin{array}{l}\text { DCS-standard: } 1800 \mathrm{MHz} \text {, pulsed with } 217 \\
\mathrm{~Hz} \text {, pulse width of } 576 \mu \mathrm{s}\end{array}$ & $\begin{array}{l}4 \text { weeks ( } 2 \text { h/day, } 5 \\
\text { days/week) }\end{array}$ & No effect & [33] \\
\hline $\begin{array}{l}\text { GSM-standard: } 900 \mathrm{MHz} \text {, pulsed with } 217 \\
\mathrm{~Hz} \text {, pulse width of } 577 \mu \mathrm{s}\end{array}$ & $\begin{array}{l}20 \text { randomly allotted } 4-\mathrm{h} \\
\text { sessions }\end{array}$ & No effect & [34] \\
\hline $\begin{array}{l}\text { GSM-standard: } 900 \mathrm{MHz} \text {, pulsed with } 217 \\
\mathrm{~Hz} \text {, pulse width of } 576 \mu \mathrm{s}\end{array}$ & $60 \min (19: 00-20: 00)$ & No effect & [35] \\
\hline \multicolumn{4}{|c|}{ 6-Hydroxymelatonin Sulfate } \\
\hline $\begin{array}{l}0.057 \mu \mathrm{T}, 60 \mathrm{~Hz} \\
0.66 \mu \mathrm{T}, 60 \mathrm{~Hz} \\
0.46 \mu \mathrm{T}, 60 \mathrm{~Hz}\end{array}$ & $\begin{array}{l}4 \text { weeks } \\
4 \text { weeks } \\
7 \text { weeks }\end{array}$ & No effect & [36] \\
\hline $\begin{array}{l}10 \mu \mathrm{T}, 50 \mathrm{~Hz} \text { (continuous) } \\
10 \mu \mathrm{T}, 50 \mathrm{~Hz} \text { (intermittent) }\end{array}$ & $9 \mathrm{~h}(23: 00-08: 00)$ & No effect & [23] \\
\hline $2-7 \mathrm{mT}$ & $9 \mathrm{~h}(22: 00-07: 00)$ & No effect & [37] \\
\hline $28.3 \mu \mathrm{T}, 60 \mathrm{~Hz}$ & $8 \mathrm{~h}(23: 00-07: 00)$ & No effect & [30] \\
\hline $100 \mu \mathrm{T}, 50 \mathrm{~Hz}$ (continuous or intermittent) & $30 \min (13: 30-16: 30)$ & No effect & [31] \\
\hline $0.7-9.1 \mu \mathrm{T}, 50 \mathrm{~Hz}$ & Overnight for 11 weeks & No effect & [38] \\
\hline $20 \mu \mathrm{T}, 50 \mathrm{~Hz}$ & 12 h (20:00-08:00) & No effect & [39] \\
\hline
\end{tabular}

\section{ELECTROMAGNETIC FIELDS AND PITUITARY - ADRENAL AXIS}

Electromagnetic fields did not influence secretion of ACTH[29]. In the majority of studies, no effect of EMF on cortisol secretion have been found[22,30,32,34,39,41] (Table 2). However, Woldanska-Okonska and Czernicki[44], studying cortisol concentration in four time points (06:00, 12:00, 16:00, and 24:00), observed different changes following chronic exposure to EMF of $2.9 \mathrm{mT}, 40 \mathrm{~Hz}$ in comparison to 25-80 $\mu \mathrm{T}, 200 \mathrm{~Hz}$. Exposure to EMF of $2.9 \mathrm{mT}, 40 \mathrm{~Hz}$ resulted in decrease of cortisol levels at 16:00 h, whereas after exposure to EMF of 25-80 $\mu \mathrm{T}, 200 \mathrm{~Hz}$, an increase in cortisol concentrations was found at 12:00 h. 
TABLE 2

Effects of Electromagnetic Fields on Concentrations of Various Hormones

\begin{tabular}{|c|c|c|c|c|}
\hline Hormone & Exposure Parameters & $\begin{array}{l}\text { Exposure } \\
\text { Duration }\end{array}$ & Outcome & Ref. \\
\hline \multirow[t]{4}{*}{$\mathrm{FSH}$} & $10 \mu \mathrm{T}, 40 \mathrm{~Hz}$ (continuous) & $9 \mathrm{~h}(23: 00-08: 00)$ & No effect & [41] \\
\hline & $10 \mu \mathrm{T}, 40 \mathrm{~Hz}$ (intermittent) & $9 \mathrm{~h}(23: 00-08: 00)$ & No effect & [41] \\
\hline & $2.9 \mathrm{mT}, 40 \mathrm{~Hz}$ & 15 days, $20 \mathrm{~min} /$ day & No effect & [42] \\
\hline & $25-80 \mu \mathrm{T}, 200 \mathrm{~Hz}$ & 15 days, $20 \mathrm{~min} /$ day & No effect & [42] \\
\hline \multirow[t]{5}{*}{ LH } & $10 \mu \mathrm{T}, 40 \mathrm{~Hz}$ (continuous) & 9 h (23:00-08:00) & No effect & [41] \\
\hline & $10 \mu \mathrm{T}, 40 \mathrm{~Hz}$ (intermittent) & $9 \mathrm{~h}(23: 00-08: 00)$ & No effect & [41] \\
\hline & $2.9 \mathrm{mT}, 40 \mathrm{~Hz}$ & 15 days, $20 \mathrm{~min} /$ day & Decrease & [42] \\
\hline & $25-80 \mu \mathrm{T}, 200 \mathrm{~Hz}$ & 15 days, $20 \mathrm{~min} /$ day & No effect & [42] \\
\hline & $\begin{array}{l}\text { GSM-standard: } 900 \mathrm{MHz} \text {, pulsed with } 217 \mathrm{~Hz} \text {, pulse } \\
\text { width of } 577 \mu \mathrm{s}\end{array}$ & 8 h $(23: 00-07: 00)$ & No effect & [32] \\
\hline \multirow[t]{3}{*}{$\mathrm{GH}$} & $20 \mu \mathrm{T}, 50 \mathrm{~Hz}$ & 12 h (20:00-08:00) & No effect & [39] \\
\hline & $1 \mu \mathrm{T}, 50 \mathrm{~Hz}$ & $10 \mathrm{~h}(22: 00-08: 00)$ & No effect & [30] \\
\hline & $\begin{array}{l}\text { GSM-standard: } 900 \mathrm{MHz} \text {, pulsed with } 217 \mathrm{~Hz} \text {, pulse } \\
\text { width of } 577 \mu \mathrm{s}\end{array}$ & 8 h $(23: 00-07: 00)$ & No effect & [32] \\
\hline \multirow[t]{4}{*}{ Prolactin } & $20 \mu \mathrm{T}, 50 \mathrm{~Hz}$ & 12 h (20:00-08:00) & No effect & [39] \\
\hline & $1 \mu \mathrm{T}, 50 \mathrm{~Hz}$ & 10 h (22:00-08:00) & No effect & [30] \\
\hline & $2.9 \mathrm{mT}, 40 \mathrm{~Hz}$ & 15 days, $20 \mathrm{~min} /$ day & Decrease & [42] \\
\hline & $25-80 \mu \mathrm{T}, 200 \mathrm{~Hz}$ & 15 days, $20 \mathrm{~min} /$ day & Decrease & [42] \\
\hline \multirow[t]{4}{*}{ TSH } & $10 \mu \mathrm{T}, 40 \mathrm{~Hz}$ (continuous) & 9 h $(23: 00-08: 00)$ & No effect & [41] \\
\hline & $10 \mu \mathrm{T}, 40 \mathrm{~Hz}$ (intermittent) & 9 h (23:00-08:00) & No effect & [41] \\
\hline & $2.9 \mathrm{mT}, 40 \mathrm{~Hz}$ & 15 days, $20 \mathrm{~min} /$ day & No effect & [43] \\
\hline & $25-80 \mu \mathrm{T}, 200 \mathrm{~Hz}$ & 15 days, $20 \mathrm{~min} /$ day & No effect & [43] \\
\hline
\end{tabular}

\section{ELECTROMAGNETIC FIELDS AND GONADAL HORMONES}

In men, chronic application of $2.9 \mathrm{mT}, 40 \mathrm{~Hz}$ and 25-80 $\mu \mathrm{T}, 200 \mathrm{~Hz}$ EMF[42] or acute exposure to EMF of $1 \mu \mathrm{T}, 50 \mathrm{~Hz}[30]$ did not affect testosterone concentrations. However, application of EMF of 25-80 $\mu \mathrm{T}$, $200 \mathrm{~Hz}$ lowered levels of estradiol, whereas EMF of $2.9 \mathrm{mT}, 40 \mathrm{~Hz}$ have no effect in men[42].

\section{CONCLUDING REMARKS}

In general, it seems that EMF exert no or very subtle effects on the endocrine system. Small differences reported in various studies may depend on different characteristics of applied magnetic fields and different experimental paradigm.

\section{ACKNOWLEDGMENTS}

The work by the authors and this review were supported by a grant from Medical University of Lodz, No. 503-129-2. 


\section{REFERENCES}

1. Portier, C.J. and Wolfe, M.S., Eds. (1998) Assessment of Health Effects from Exposure to Power-Line Frequency Electric and Magnetic Fields. NIEHS Working Group Report, NIH Publication No. 98-3981.

2. $\quad$ Basset, C.A. (1993) Beneficial effect of electromagnetic fields. J. Cell. Biochem. 4, 387-393.

3. Fisher, G.(1996) Grundlagen der Quanten-Therapie. Hecateus Verlagsanstalt, Tiesenberg.

4. Repacholi, M.H. and Greenebaum, B. (1999) Interaction of static and extremely low frequency electric and magnetic fields with living systems: health effects and research needs. Bioelectromagnetics 20, 133-160.

5. $\quad$ Moulder, J.E. (1998) Power-frequency fields and cancer. Crit. Rev. Biomed. Eng. 26, 1-116.

6. Hayes, D.L. and Vlietstra, R.E. (1993) Pacemaker malfunction. Ann. Intern. Med. 119, 828-835.

7. Sobel, E., Dunn, M., Davanipour, Z., Qian, Z., and Chui, H. (1996) Elevated risk of Alzheimer's disease among workers with likely electromagnetic exposure. Neurology 47, 1477-1481.

8. $\quad$ Robert, E. (1996) Teratogen update: electromagnetic fields. Teratology 54, 305-331.

9. Hackman, R.M. and Graves, H.B. (1981) Corticosterone levels in mice exposed to high intensity electric fields. Behav. Neural Biol. 32, 201-213.

10. Free, M.M., Kaune, W.T., Phillips, R.D., and Cheng, H.C. (1981) Endocrinological effects of strong $60 \mathrm{~Hz}$ electric fields on rats. Bioelectromagnetics 2, 105-121.

11. Quinaln, W.J., Petrondas, D., Lebda, N., Pettit, S., and Michaelson, S.M. (1985) Neuroendocrine parameters in the rat exposed to 60-Hz electric fields. Bioelectromagnetics 6, 381-389.

12. Zagorskaia, E.A. and Rodina, G.P. (1990) Reaction of the endocrine system and peripheral blood of rats to a single and chronic exposure to pulsed low-frequency electromagnetic field. Kosm. Biol. Aviakosm. Med. 24, 56-60 [Russian]).

13. Forgacs, Z., Thuroczy, G., Paksy, K., and Szabo, L.D. (1998) Effects of sinusoidal $50 \mathrm{~Hz}$ magnetic field on the testosterone production of mouse primary Leydig cell culture. Bioelectromagnetics 19, 429-431.

14. Mostafa, R.M., Mostafa, Y.M., and Ennaceur, A. (2002) Effects of exposure to extremely low-frequency magnetic field of $2 \mathrm{G}$ intensity on memory and corticosterone levels in rats. Physiol. Behav. 76, 589-595.

15. Burch, J.B., Reif, J.S., Yost, M.G., Keefe, T.J., and Pitrat, C.A. (1998) Nocturnal excretion of a urinary melatonin metabolite among electric utility workers. Scand. J. Work Environ. Health 24, 183-189.

16. Burch, J.B., Reif, J.S., Yost, M.G., Keefe, T.J., and Pitrat, C.A. (1999) Reduced excretion of a melatonin metabolite in workers exposed to $60 \mathrm{~Hz}$ magnetic fields. Am. J. Epidemiol. 150, 27-36.

17. Burch, J.B., Reif, J.S., and Yost, M.G. (1999) Geomagnetic disturbances are associated with reduced nocturnal excretion of a melatonin metabolite in humans. Neurosci. Lett. 266, 209-212.

18. Burch, J.B., Reif, J.S., Noonan, C.W., and Yost, M.G. (2000) Melatonin metabolite levels in workers exposed to 60Hz magnetic fields: work in substations and with 3-phase conductors. J. Occup .Environ. Med. 42, 136-142.

19. Davis, S., Kaune, W.T., Mirick, D.K., Chen, C., and Stevens, R.G. (2001) Residential magnetic fields, light-at-night, and nocturnal urinary 6-sulfatoxymelatonin concentration in women. Am. J. Epidemiol. 154, 591-600.

20. Levallois, P., Dumont, M., Touitou, Y., Gingras, S., Masse, B., Gauvin, D., Kroger, E., Bourdages, M., and Douville, P. (2001) Effects of electric and magnetic fields from high-power lines on female urinary excretion of 6sulfatoxymelatonin. Am. J. Epidemiol. 154, 601-609.

21. Prato, F.S., Ossenkopp, K.P., Kavaliers, M., Uksik, P., Nicholson, R.L., Drost, D., and Sestrini, E.A. (1989) Effects of exposure to magnetic resonance imaging on nocturnal serum melatonin and other hormone levels in adult males. Preliminary findings. J. Bioelectricity 7, 169-180.

22. Schiffman, J.S., Lasch, H.M., Rollag, M.D., Flanders, A.E., Brainard, G.C., and Burk, D.L. (1994) Effect of magnetic resonance imaging on the normal human pineal body: measurements of plasma melatonin levels. J. Magn. Reson. Imaging 4, 7-11.

23. Selmaoui, B., Lambrozo, J., and Touitou, Y. (1996) Magnetic fields and pineal function in humans: evaluation of nocturnal acute exposure to extremely low frequency magnetic fields on serum melatonin and urinary 6hydroxymelatonin rhythm. Life Sci. 58, 1539-1549.

24. Graham, C., Cook, M.R., Riffle, D.W., Gerkovich, M.M., and Cohen, H.D. (1996) Nocturnal melatonin levels in human volunteers exposed to intermittent $60 \mathrm{~Hz}$ magnetic field. Bioelectromagnetics 17, 263-273.

25. Graham, C., Cook, M.R., and Riffle, D.W. (1997) Human melatonin during continuous magnetic field exposure. Bioelectromagnetics 18, 166-171.

26. Wood, A.W., Armstrong, S.M., Sait, M.L., Devine, L., and Martin, M.J. (1998) Changes in human plasma melatonin profiles in response to $50 \mathrm{~Hz}$ magnetic field exposure. J. Pineal Res. 25, 116-127.

27. Karasek, M., Woldanska-Okonska, M., Czernicki, J., Zylinska, K., and Swietoslawski, J. (1998) Chronic exposure to $2.9 \mathrm{mT}, 40 \mathrm{~Hz}$ magnetic field reduces melatonin concentrations in humans. J. Pineal Res. 25, 240-244.

28. Karasek, M., Czernicki, J., Woldanska-Okonska, M., Zylinska, K., and Swietoslawski J. (2000) Chronic exposure to 25-80 $\mu \mathrm{T}, 200 \mathrm{~Hz}$ magnetic field does not influence serum melatonin concentrations in patients with low back pain. $J$. Pineal Res. 29, 81-85.

29. Akerstedt, T., Arnetz, B., Ficca, G., Paulsson, L.E., and Kallner, A. (1999) A 50-Hz electromagnetic field impairs sleep. J. Sleep Res. 8, 77-81. 
30. Graham, C., Sastre, A., Cook, M.R., and Gerkovich, M.M. (2001) All-night exposure to EMF does not alter urinary melatonin, 6-OHMS or immune measures in older men and women. J. Pineal Res. 31, 109-113.

31. Crasson, M., Beckers, V., Pequeux, Ch., Claustrad, B., and Legros, J.J. (2001) Daytime 50 Hz magnetic field exposure and plasma melatonin and urinary concentration profiles in humans. J. Pineal Res. 31, 234-241.

32. Mann, K., Wagner, P., Brunn, G., Hassa, F., Hiemke, C., and Röschke, J. (1998) Effects of pulsed high-frequency electromagnetic fields on the neuroendocrine system. Neuroendocrinology 67, 139-144.

33. de Seze, R., Ayoub, J., Peray, P., Miro, L., and Touitou, Y. (1999) Evaluation in humans of the effects of radiocellular telephones on the circadian patters of melatonin secretion, a chronobiological rhythm marker. J. Pineal Res. 27, 237242.

34. Radon, K., Parera, D., Rose, D.M., Jung, D., and Vollrath, L. (2001) No effects of pulsed radio frequency electromagnetic fields on melatonin, cortisol, and selected markers of the immune system in man. Bioelectromagnetics 22, 280-287.

35. Bortkiewicz, A., Pilacik, B., Gadzicka, E., and Szymczak, W. (2002) The excretion of 6-hydroxymelatonin sulfate in healthy young men exposed to electromagnetic fields emitted by cellular phone - an experimental study. Neuroendocrinol. Lett. 23(Suppl. 1), 88-91.

36. Wilson, B.W., Wright, C.W., Morris, J.E., Buschbom, R.L., Brown, D.P., Miller, D.L., Flannigan, R., and Anderson, L.E. (1990) Evidence for an effect of ELF electromagnetic fields on human pineal gland function. J. Pineal Res. 9, 259-269.

37. Haugsdal, B., Tynes, T., Rotnes, J.S., and Griffiths, D. (2001) A single nocturnal exposure to 2-7 militesla static magnetic field does not inhibit the excretion of 6-sulfatoxymelatonin in healthy young men. Bioelectromagnetics 22, $1-6$.

38. Hong, S.C., Kurokawa, Y., Kabuto, M., and Ohtsuka, R. (2001) Chronic exposure to ELF magnetic fields during night sleep with electric sheet: effects on diurnal melatonin rhythms in men. Bioelectromagnetics 22, 138-143.

39. Kurokawa, Y., Nitta, H., Imai, H., and Kabuto, M. (2003) Acute exposure to $50 \mathrm{~Hz}$ magnetic fields with harmonic and transient components: lack of effects on nighttime hormonal secretion in men. Bioelectromagnetics 24, 12-20.

40. Karasek, M. and Lerchl, A. (2002) Melatonin and magnetic fields. Neuroendocrinol. Lett. 23(Suppl. 1), 84-87.

41. Selmaoui, B., Lambrozo, J., and Touitou, Y. (1997) Endocrine functions in young men exposed for one night to a 50Hz magnetic field. A circadian study of pituitary, thyroid and adrenocortical hormones. Life Sci. 61, 473-486.

42. Woldanska-Okonska, M., Karasek, M., and Czernicki, J. (2004) The influence of chronic exposure to low frequency pulsating magnetic fields on concentrations of FSH, LH, prolactin, testosterone and estradiol in men with back pain. Neuroendocrinol. Lett. 25, 201-206.

43. Woldanska-Okonska, M. and Czernicki, J. (2003) Effects of low frequency pulsating magnetic fields used in magnetotherapy and magnetostimulation on thyroid gland hormones in humans. Med. Pracy 54, 335-339 [Polish].

44. Woldanska-Okonska, M. and Czernicki, J. (2003) Effects of low frequency pulsating magnetic fields used in magnetotherapy and magnetostimulation on cortisol secretion in humans. Med. Pracy 54, 29-32 [Polish].

\section{This article should be referenced as follows:}

Karasek, M. and Woldanska-Okonska, M. (2004) Electromagnetic fields and human endocrine system.

TheScientificWorldJOURNAL 4(S2), 23-28. 

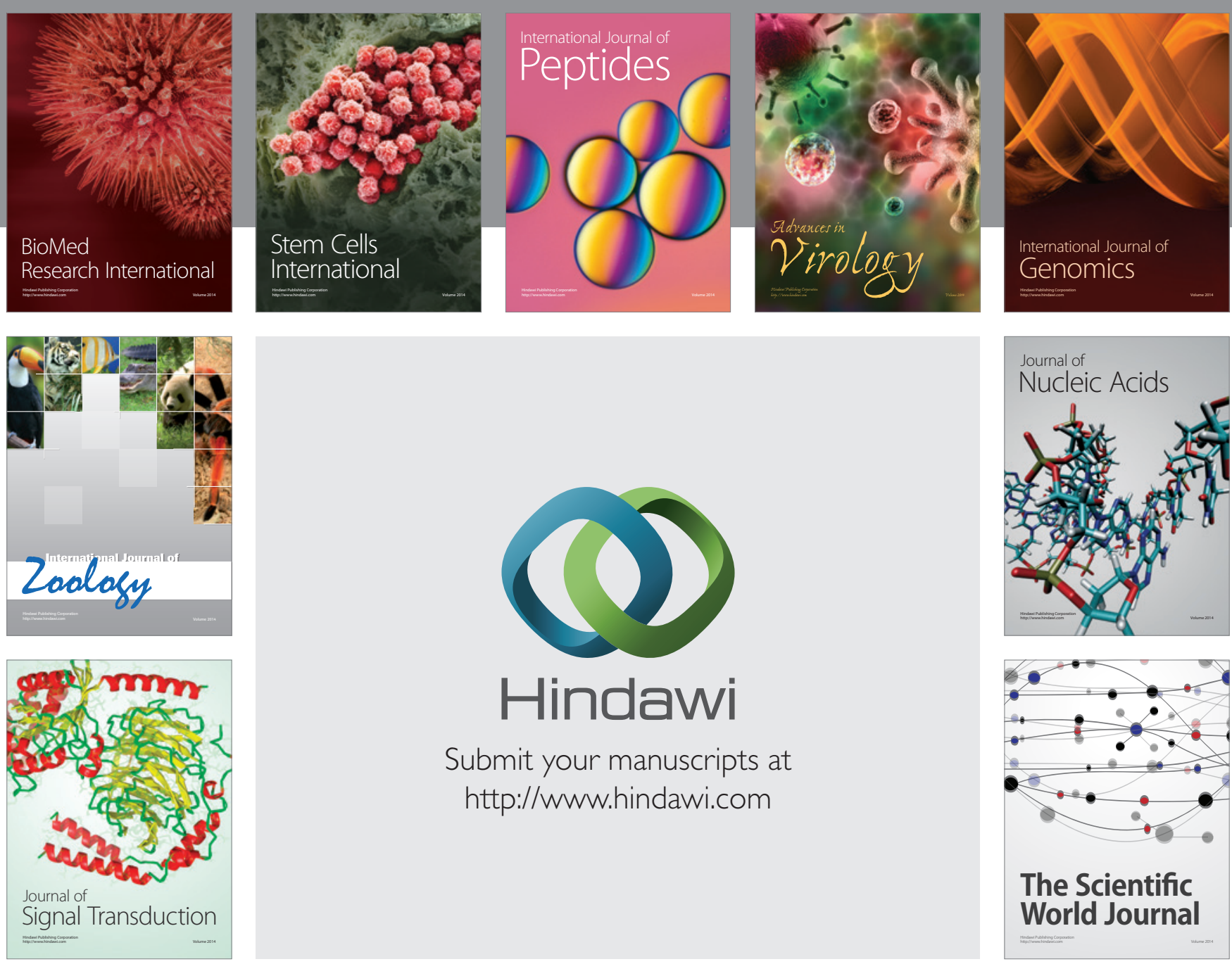

Submit your manuscripts at

http://www.hindawi.com
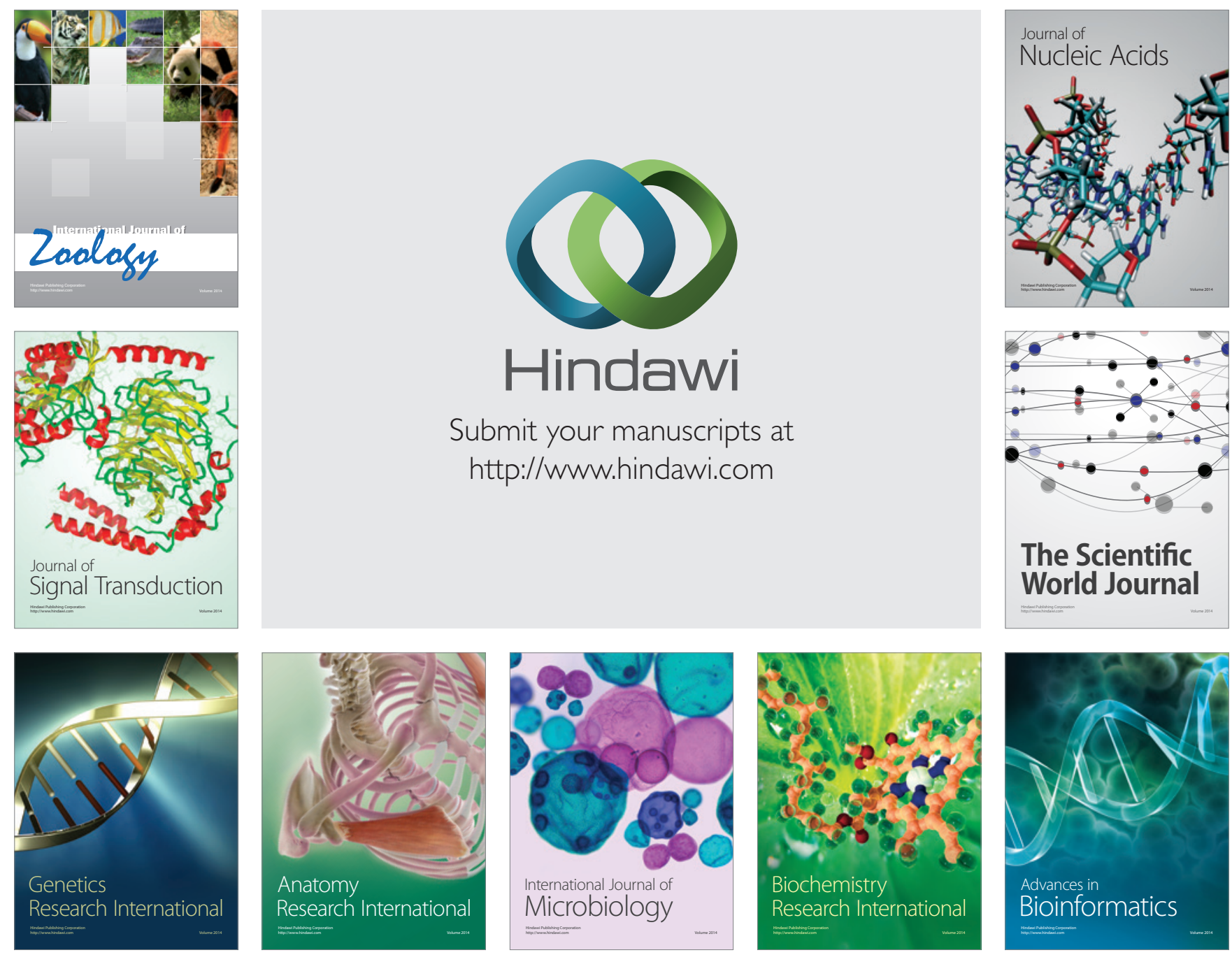

The Scientific World Journal
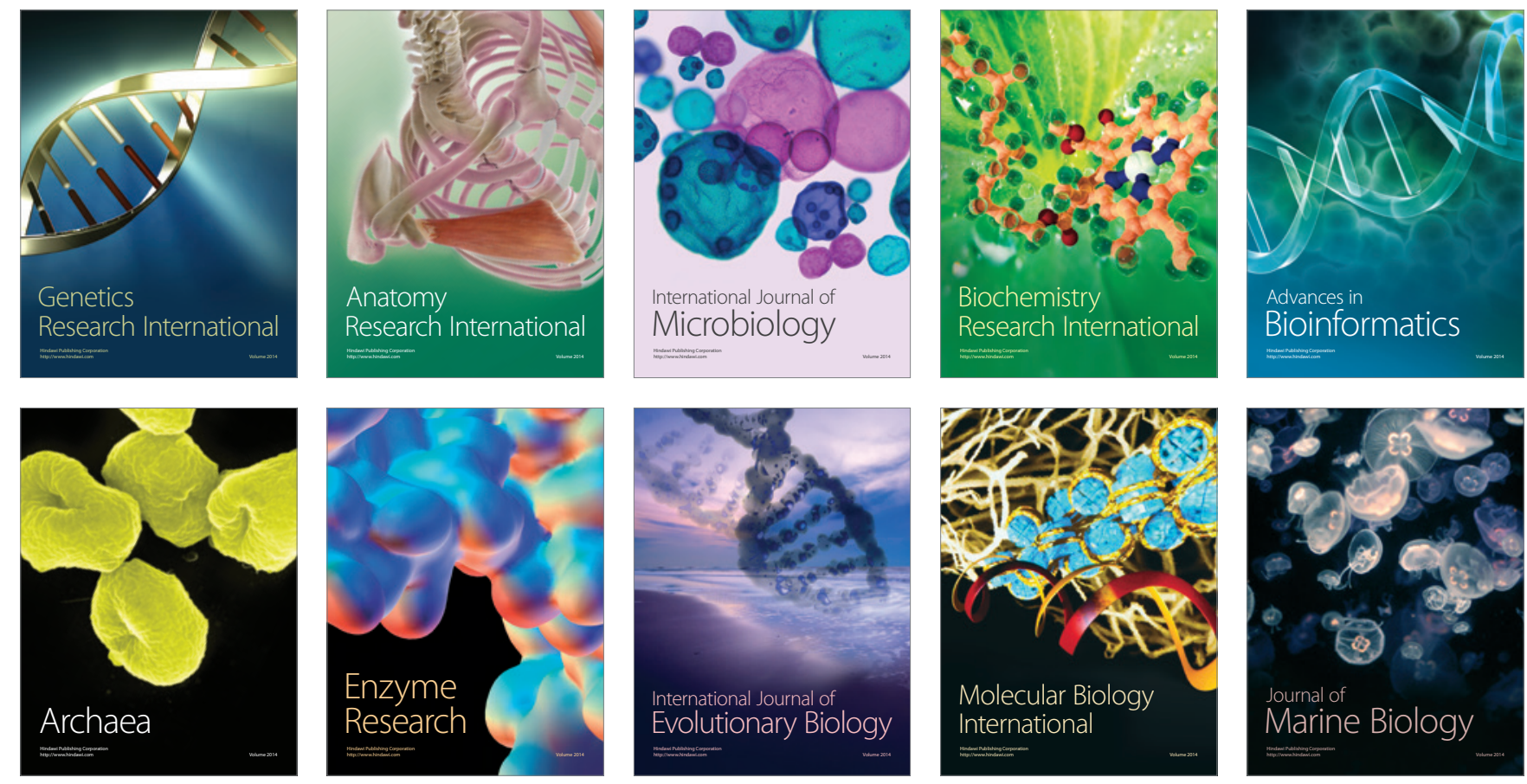